\title{
Reproductive biology of Charybdis (Goniohellenus) longicollis Leene, 1938 (Brachyura: Portunidae), in the north-eastern Mediterranean Sea, Turkey
}

\author{
CANAN TURELI AND IREM NUR YESILYURT \\ Department of Basic Sciences, Faculty of Fisheries, University of Cukurova, Balcall-Adana, Turkey \\ e-mail:cantur@cu.edu.tr
}

\begin{abstract}
The swimming crab, Charybdis (Goniohellenus) longicollis Leene, 1938, is a Lessepsian migrant into the Mediterranean and little is known about its biology in Iskenderun Bay, north-eastern Mediterranean, Turkey. The size of crabs, sex-ratio and spawning period of this species was defined from 951 specimens in order to understand their reproduction and development in the North-Eastern Mediterranean Sea. The crabs were found to occur throughout the year. Carapace width (CW) ranged between 7.22 to $100.60 \mathrm{~mm}$ and total weight ranged from 1.34 to $164.09 \mathrm{~g}$. Male-female sex ratio was 0.6:1. Highest gonado-somatic index (GSI) was seen in March and September for females and in May for males. Ovigerous females were present throughout the year, with peak spawning activity in July and September. The CW of the ovigerous female crabs ranged between 23.71 and $95.93 \mathrm{~mm}$. In winter months, GSI of males and females decreased. However, spawning season of C. (G.) longicolis in Yumurtalık Cove was observed throughout the year.
\end{abstract}

Keywords: Charybdis (Goniohellenus) longicollis, Crustacea, Iskenderun Bay, Lessepsian, Portunidae, Reproductive biology

\section{Introduction}

The swimming crab, Charybdis (Goniohellenus) longicolis Leene, 1938, is known to occur in the East African coast, the Red Sea, the Gulf of Aden, the Gulf of Oman and the Arabian Gulf. C. (G.) longicollis was first recorded in the Mediterranean in 1954 from Mersin Bay, Turkey (Holthuis, 1961). Since then, it has invaded and established a large population throughout the northeastern Mediterranean coast of Turkey (Ozcan et al., 2005; Marun, 2016) and has been recorded all along the Levantine coast, from Egypt to the Aegean coast of Turkey. Portunidae is the most successful family in colonisation of Mediterranean coasts. In fact, among the 54 Brachyura listed by Galil et al. (2015), 14 species belong to this family with 6 species in the genus Charybdis (Kondylatos et al., 2017).

Previous studies on C. (G.) longicollis have reported the species' distribution (Kocatas,1981; Kocatas and Katagan,1994; 2003; Enzenross and Enzenross, 1995; Zenetos et al., 2005; Naderloo and Sari, 2007), parasites (Oksnebjerg et al., 1997; Galil and Innocenti, 1999; Innocenti et al., 2010; Ozcan and Katagan, 2016; Innocenti et al., 2017), width/length-weight and widthlength relationships from the north-eastern Mediterranean coast of Turkey (Sangün et al., 2009) and sex distribution, morphometric aspects, condition factor and fecundity in Iskenderun Bay (Marun, 2016).
However, very little is known about the biology of C. (G.) longicollis in any area of its distribution, probably because it does not reach a commercial size and value. In Turkey, there have been no studies on the reproductive biology of the species. The purpose of this study was to investigate on the reproductive biology of female $C$. (G.) longicollis in Iskenderun Bay, Yumurtalık Cove, Turkey.

\section{Materials and methods}

C. (G.) longicollis were sampled monthly in the Yumurtalık Cove $36^{\circ} 42^{\prime} \mathrm{N} ; 35^{\circ} \mathrm{E}-35^{\circ} 49^{\prime} \mathrm{E}$ between July 2014 and June 2015 using a small shrimp trawl (15 m head rope with $14 \mathrm{~mm}$-mesh cod end) towed for $45 \mathrm{~min}$ at three different depths; 0-10, 10-20 and 20-50 m. Bottom water salinity, temperature, dissolved oxygen (DO) and depth were measured at each station using a CTD probe (YSI 6600 multiparameter probe) and all individuals were held in ice until laboratory analyses.

In the laboratory, crabs were sorted sex-wise and individual records of carapace widths $(\mathrm{CW}, \mathrm{mm})$ and total weight (TW, g) were taken. Missing legs were noted and the opposing leg, if present, was removed, weighed and its weight was added to the total (Gelpi et al., 2009).

The total number of male and female crabs was used to calculate the sex ratio per month. Chi-square $\left(\chi^{2}\right)$ statistic was used to test the difference between the sexes. 
Juveniles and adults (including ovigerous females) were described by the form of the abdomen and the presence of egg masses (Williams, 1974). In females, ovaries were dissected out and examined to classify the maturity stages (gonad development stages) (Wenner, 1989). Four stages were categorised as follows: stage 1 immature ovary, white; stage 2 - maturing or developing ovary, light yellow; stage 3 - mature ovary, yellow/orange and stage 4 - ripe ovary, dark orange or red.

Weight of the ovaries of crabs was measured to the nearest $0.001 \mathrm{~g}$. GSI was calculated using the following formula (Soundarapandian et al., 2013):

GSI $=($ Wet weight of the gonad/Wet weight of the body $) \times 100$

Fecundity was estimated by analysing 118 female crabs. Egg mass colours were classified as bright orange $=1$, dark orange $=2$, brown $=3$, dark brown $=4$ and black $=5$ (Jivoff et al., 2007) and then, the egg masses were removed from the pleopods for measurement of weight. From each egg mass, three $0.01 \mathrm{~g}$ subsamples of eggs were randomly separated, weighed, spread on the microscope slide with one side striped with glycerol (30\%) and the eggs were counted under a stereo microscope (Prager et al., 1990). The number of eggs in the sample was taken as the average numbers of eggs from the three subsamples. The total number of eggs for each female was extrapolated from the whole egg mass. Linear and logarithmic regression analyses and exponential functions were used to establish the relationships between fecundity and body size (CW, TW) and egg mass weight (EW). Differences in the regression slope for the relationships between fecundity and body size were analysed by t-test. Spawning peak was determined as the months with highest number of ovigerous females.

The size at first sexual maturity of females was determined using the minimum size class data of the ovigerous females.
Statistical tests involved the use of simple regression analysis and ANOVA (Freund and Wilson, 2003). SPSS was used for all statistical analyses. All statistical effects were considered significant at $\mathrm{p}=0.05$.

\section{Results}

Water temperature ranged from 15.93 to $30.13^{\circ} \mathrm{C}$ and the lowest and highest values were measured at $0-10 \mathrm{~m}$ during all the sampling cruises. The average salinity ranged between 37.40 $\pm 0.65 \%$ (March 2015) and 38.61 $\pm 0.78 \%$ (October 2014). Temperature and salinity were seasonally variable. The mean dissolved oxygen (DO) rate ranged from 5.99 to $8.43 \mathrm{mg} \mathrm{l}^{-1}$. There was also a seasonal trend for dissolved oxygen. Hypoxic $\left(<2 \mathrm{mg} \mathrm{l}^{-1}\right)$ bottom water was not found in any station in the Yumurtalik Cove.

During the study period, a total of 951 crabs, which consisted of 523 females (55\%), 213 of which were ovigerous), 350 males (36.8\%) and 78 juveniles (8.2\%) were caught. The crabs were abundant between June (17.45\%) and July to December (61.30\%).

Male crabs were larger than females $\left(\mathrm{F}_{1-3}=65.06\right.$; $\mathrm{P}=0.00), \mathrm{CW}$ in male ranged between 14.73-71.88 $\mathrm{mm}(42.29 \pm 0.43)$ and in females varied from 7.12 to $100.6 \mathrm{~mm}$ (Table 1).

The overall male to female ratio showed female dominance during the study period $(0.6: 1)$. Chi-square $\left(\chi^{2}\right)$ test indicated that the difference between the numbers of males and females was significant $(\mathrm{p}<0.05)$ (Table 2$)$.

The monthly distribution of maturity stages of females are shown in Fig. 1. Maturity stage 1 occurred during all months. In December, all the specimens were in this stage. Fully mature ovaries were seen throughout the sampling period except in December and January, with the highest percentages in September and July.

GSI values for the 170 females ranged from 1.63 to $5.37 \%$ with a mean value of $3.38 \pm 1.17 \%$. Those of 172 males ranged from 0.17 to $0.58 \%$ with a mean of

Table 1. Morphological characteristics of $C$. (G.) longicollis in Yumurtal1k Cove

\begin{tabular}{lllll}
\hline Sex & Number & CW $(\mathrm{mm})$ & CL $(\mathrm{mm})$ & W $(\mathrm{g})$ \\
\hline Male & 350 & $14.73-71.88$ & $4.49-57.92$ & $1.34-129.53$ \\
& & $(42.29 \pm 0.43)$ & $(25.98 \pm 0.28)$ & $(17.05 \pm 0.57)$ \\
Female & 310 & $17.22-100.60$ & $16.33-61.68$ & $1.80-164.09$ \\
& & $(38.75 \pm 0.49)$ & $(23.20 \pm 0.21)$ & $(11.74 \pm 0.76)$ \\
Ovigerous female & 213 & $23.71-95.93$ & $14.58-33.36$ & $2.97-88.84$ \\
& & $(34.57 \pm 0.42)$ & $(21.18 \pm 0.17)$ & $(9.54 \pm 0.43)$ \\
Juvenile & 78 & $23.64-48.42$ & $13.17-32.10$ & $2.51-31.99$ \\
& & $(33.19 \pm 0.66)$ & $(20.45 \pm 0.43)$ & $(8.09 \pm 0.66)$ \\
\hline
\end{tabular}

Values are : Minimum-Maximum; Values in parantheses refers to Mean $\pm \mathrm{SE}$

CW: Carapace width, CL: Carapace length, W: Body weight, 
Table 2. Sex ratio of $C$. (G.) longicollis in Yumurtalık Cove

\begin{tabular}{llllll}
\hline Month & Male & Female & Male:Female & \% of Female & $\chi^{2}$ \\
\hline Jul & 39 & 82 & $0.5: 1$ & 67.7 & $0.00^{*}$ \\
Aug & 71 & 79 & $0.9: 1$ & 52.6 & 0.51 \\
Sep & 43 & 49 & $0.9: 1$ & 53.2 & 0.53 \\
Oct & 33 & 49 & $0.7: 1$ & 59.7 & 0.07 \\
Nov & 29 & 69 & $0.3: 1$ & 70.4 & $0.00^{*}$ \\
Dec & 19 & 7 & $2.7: 1$ & 26.9 & $0.01^{*}$ \\
Jan & 7 & 9 & $0.8: 1$ & 56.2 & 0.61 \\
Mar & 17 & 26 & $0.6: 1$ & 60.4 & 0.17 \\
Apr & 10 & 21 & $0.5: 1$ & 67.7 & $0.04^{*}$ \\
May & 22 & 36 & $0.6: 1$ & 62.0 & 0.06 \\
Jun & 60 & 96 & $0.6: 1$ & 61.5 & $0.00^{*}$ \\
Total & 350 & 523 & $0.6: 1$ & 59.9 & $0.00^{*}$ \\
\hline
\end{tabular}

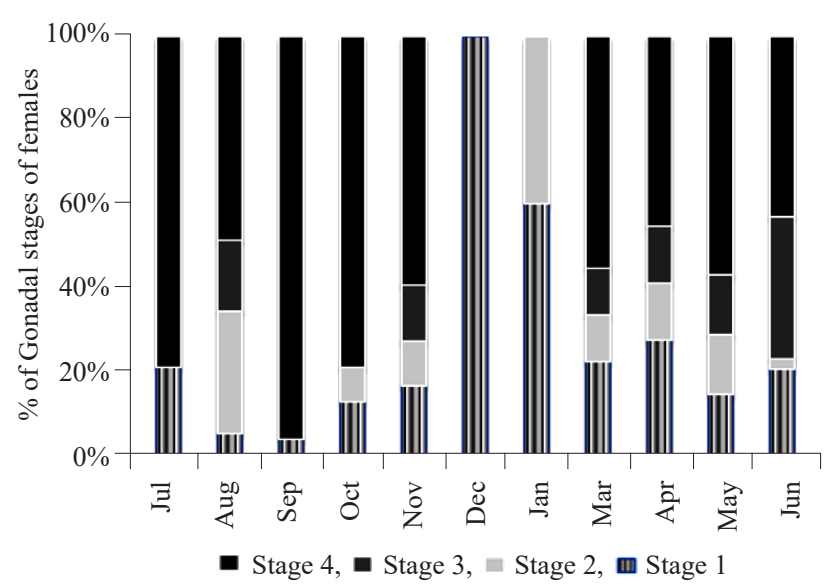

Fig. 1. Monthly distribution (\%) of $C$. (G.) longicollis female maturity stages

$0.35 \pm 0.14 \%$. In females, the mean GSI values increased with two peaks in September and March. They declined in December and had a slight oscillation in June. In males, the highest GSI values were estimated for November and May. In winter months, the GSI values of males and females decreased. The spawning season for females was observed two times in spring and fall months.

Ovigerous females were collected during the study period. Higher proportion of ovigerous females occurred from June to November. The highest numbers of ovigerous individuals were caught in July (Fig. 2). Ovigerous female crabs ranged between 23.71 and $95.93 \mathrm{~mm}$ in $\mathrm{CW}$ and 2.97 and $88.84 \mathrm{~g}$ in body weight (Table 1 ).

Fecundity of $C$. (G.) longicollis was $99176 \pm 51899$ eggs, ranging between $22200 \pm 8879 \quad(\mathrm{CW}=22.33$ $\mathrm{mm})$ and $292608 \pm 38728$ eggs $(\mathrm{CW}=45.21 \mathrm{~mm})$. The mean fecundity increased with increasing total weight $\left(\mathrm{F}_{9-108}=7.96 ; \mathrm{p}<0.05\right)$ and mean fecundity differences among size classes were significant $\left(\mathrm{F}_{4-113}=11.42\right.$;

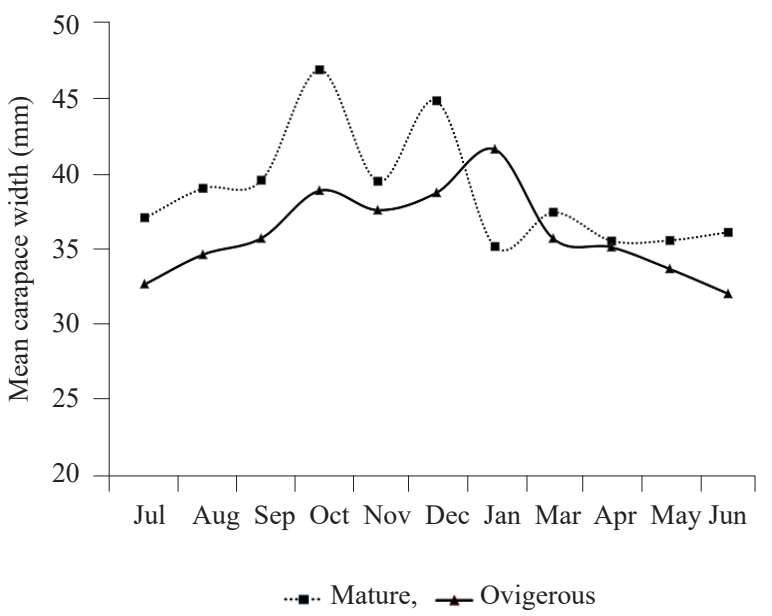

Fig. 2. Monthly mean size $(\mathrm{CW})$ of mature and ovigerous C. (G.) longicollis females in Yumurtalık Cove

$\mathrm{p}<0.05)$. Mean fecundity very weakly correlated with carapace width $(\mathrm{r}=0.17, \mathrm{p}<0.01)$; however, there was a high and positive correlation of weight $(r=0.57, p<0.01)$ with egg weight $(r=0.67, p<0.01)$ and mean fecundity. The regression slopes for fecundity-weight $(\mathrm{t}=7.5$; $\mathrm{p}=0.00)$ and fecundity-egg weight $(\mathrm{t}=12.2 ; \mathrm{p}=0.00)$ were significant. The regression between fecundity and weight was $\mathrm{F}=26973.9+7158.6^{*} \mathrm{~W}\left(\mathrm{R}^{2}=0.330 ; \mathrm{F}_{1-117}=57.1\right.$; $\mathrm{p}=0.00)$. The estimated regression equation of egg weight on fecundity was $\mathrm{LnF}=11.29+0.94^{*} \mathrm{Ln}$ EW $\left(\mathrm{R}^{2}=0.563\right.$; $\left.\mathrm{F}_{1-117}=149.6 ; \mathrm{p}=0.00\right)$.

\section{Discussion}

In this study, females were found to be dominant in the population. Similar observation was reported by Sangun et al. (2009) and by Ozcan and Katagan (2016) in Iskenderun Bay. In contrast, Marun (2016) reported that male crabs were dominant in the population ( $\mathrm{M}: \mathrm{F}=1: 0.88)$. Pereira et al. (2009) stated that predominance of adult females is seen mainly in areas of higher salinity. The 
overall male to female ratio through the year was $0.6: 1$ in this study. which could be attributed to high salinity and temperature.

Sangün et al. (2009) reported the mean carapace width of $C$. (G.) longicollis population as $38.13 \pm 0.54 \mathrm{~mm}$ (22.46$59.06 \mathrm{~mm})$ and the population's mean carapace width as $23.66 \pm 0.32 \mathrm{~mm}(14.18-35.71 \mathrm{~mm})$. They stated that males had mean carapace width of $25.44 \pm 0.58 \mathrm{~mm}$ $(14.18-35.71 \mathrm{~mm})$ while this value for the females was $22.59 \pm 0.34 \mathrm{~mm}(14.19-31.85 \mathrm{~mm})$ in Iskenderun Bay. Ozcan and Katagan (2016) reported that largest number of crabs were between 30 and $45 \mathrm{~mm} \mathrm{CW}$. The crabs captured ranged from 0.6 to $50.75 \mathrm{~g}$ in weight. Marun (2016) stated that the distribution of carapace width of the Lessepsian crabs ranged between $19.2 \mathrm{~mm}$ and $67.3 \mathrm{~mm}$, with a mean value of $39.97 \pm 0.23 \mathrm{~mm}$, while the total weight values varied between a minimum of $0.8 \mathrm{~g}$ and a maximum of $50.75 \mathrm{~g}$. In the present study, the mean $\mathrm{CW}$ of the crabs were similar, while the minimum values were lower and the maximum values were higher (Table 1 ). The reproductive season for the females was observed with two peaks in spring and fall months in the Iskenderun Bay, with ripe females (maturity stage 4) occurring from March to November, with the highest percentages in September and July and immature females (maturity stage 1) and ovigerous females occurring in all the months. Spawning is correlated with seasonal changes in sea temperature (Dhawan et al., 1976). Spawning usually occurs in waters with temperature and salinity values favourable for hatching of eggs and growth of larvae. The salinity and temperature range inside the Yumurtalık Cove seemed to characterise it as a spawning area. The prevalence of mature females as well as the high percentage of ovigerous females indicates that the invasion of $C$. (G.) longicollis is complete and the species is well established within the area, as suggested by Rabaoui et al. (2015).

Marun (2016) caught ovigerous females from April to November. Eggs of 31 females were counted, and the mean fecundity of $C$. (G.) longicollis was estimated as 4058.88 \pm 640.01 eggs per female (137-15047 eggs per female). The mean fecundity in the presesnt study was lower. Variations in fecundity may have been caused by several factors such as the technique used for counting eggs, time and stage of embryonic development of eggs at the time of counting and genetic characteristics of the populations (Severino-Rodrigues et al., 2013).

Fecundity in brachyuran crabs is variable and highly dependent on the size of females (Perry and Vanderkooy, 2015). In the present study, the mean fecundity increased as total body weight increased and there was significant difference between the size classes. Marun (2016) estimated the regression between fecundity and weight relationship as $\mathrm{F}=976.72^{*} \mathrm{~W}-832.4572^{*} \mathrm{~W}-832.45\left(\mathrm{R}^{2}=0\right.$, 4205), which is similar to the results obtained in the presesnt study.

This study provides useful information on the aspects of the reproductive status of $C$. longicolis in the Mediterranean Sea. The population, characterised by densities of adult and ovigerous female specimens, confirms that $C$. (G.) longicollis is well established in the Mediterranean coast of Turkey. Further studies are needed for assessing the potential relationships with other brachyuran species in order to foresee possible negative impacts due to the invasion.

\section{Acknowledgements}

This study was supported by Cukurova University Scientific Research Projects Coordination Unit (Project No: SUF2013YL6). The authos thank the crew of commercial trawler "MAVI SU 3" for carrying out the trawling operations and Ahmet Nevzat Ilhan for help in the laboratory studies.

\section{References}

Dhawan, R. M., Dwivedi, S. N. and Rajamanickam, G. M. 1976. Ecology of the blue crab Portunus pelagicus (Linnaeus) and its potential fishery in Zuari Estuary. Indian J. Fish., 23: $57-64$

Enzenross, R. and Enzenross, L. 1995. Erstnachweise indopazifischer Brachyura (Crustacea: Decapoda) von der turkischen Mittelmeerküste. Stuttgarter Beitrage zur Naturkunde, 521: 1-4.

Freund, R. J. and Wilson, W. J. 2003. Statistical methods. Acedemic Press, San Diego, USA, 673 pp.

Galil, B. S. and Innocenti, G. 1999. Notes on the population structure of the portunid crab Charybdis longicollis Leene, parasitised by the rhizocephalan Heterosaccus dollfusi Boschma, off the Mediterranean coast of Israel. Bull. Mar. Sci., 64(3): 451-63.

Galil, B. S., Froglia, C. and Noel, P. 2015. Looking back, looking ahead: The CIESM Atlas, Crustaceans. Manag. Biol. Invasion, 6: 171-175. doi: http://dx.doi.org/10.3391/ mbi.2015.6.2.07

Gelpi, C. G., Condrey, R. E., Fleeger, J. W. and Dubois, S. F. 2009. Discovery, evolution and implications of blue crab, Callinectes sapidus, spawning, hatching and foraging grounds in federal (US) waters offshore of Louisiana. Bull. Mar. Sci., 85(3): 203-222.

Holthuis, L. B. 1961. Report on a collection of Crustacea Decapoda and Stomatopoda from Turkey and Balkans. Zool. Verhan, 47: 1-67.

Innocenti, G. and Galil, B. S. 2010. Invasive host, Charybdis longicollis (Decapoda: Brachyura: Portunidae) and invasive 
parasite, Heterosaccus dollfusi (Cirripedia: Rhizocephala: Sacculinidae). Rapp. Comm. Int. Mer Medit., 39: 545.

Innocenti, G., Stasolla, G., Goren, M., Stern, N., Levitt-Barmats, Y., Diamant, A. and Galil, B. S. 2017. Going down together: invasive host, Charybdis longicollis (Decapoda: Brachyura: Portunidae) and invasive parasite, Heterosaccus dollfusi (Cirripedia: Rhizocephala: Sacculinidae) on the upper slope off the Mediterranean coast of Israel. Mar. Biol. Res., 13(2): 229-236. doi.org/10.1080/17451000.2016.1240873

Jivoff, P., Hines, A. H. and Quackenbush, L. S. 2007. Reproduction biology and embryonic development. In: Kennedy, V. S. and Cronin, L. E. (Eds), The blue crabs Callinectes sapidus. Maryland Sea Grant, p. 255-286.

Kocatas, A. 1981. Liste preliminaire et repartition des Crustaces Decapodes des eax Turques. Rapports et procesVerbaux des Reunions Commission Internationale pourl' Exploration Scientifique de la Mer Méditerranée, 27(2): 161-162.

Kocatas, A. and Katagan, T. 1994. Turkiye denizleri biyolojik çeşitliliginde Lesepsiyen (Suveys Kanalı) Decapod ve Stomatopod türlerinin etkisi. XII. Ulusal BiyolojiKongresi, Edirne, p. 290-294, (In Turkish)

Kocatas, A. and Katagan, T. 2003. The decapod crustacean fauna of the Turkish Seas. Zoology in the Middle East, 29: 63-74. doi.org/10.1080/09397140.2003.10637971.

Kondylatos, G., Kampouris, T. E., Kouloumperis, V. and CorsiniFoka, M. 2017. The Indo-Pacific brachyuran Charybdis (Gonioinfradens) paucidentatus (Milne Edwards 1861) (Brachyura, Portunidae) in the Cyclades, Aegean Sea. Turkish J. Zool., 41: 1118-1120. DOI: 10.3906/zoo-1612-48.

Marun, S. 2016. Some biological characteristics of Lessepsian crab Charybdis longicollis Leene, 1938 (Portunidae: Decapoda) in Iskenderun Bay. Graduate Thesis, Iskenderun Technical University, Institute of Engineering and Science, Department of Fisheries, Iskenderun/Hatay, (In Turkish).

Naderloo, R. and Sari, A. 2007. Subtidal crabs of the Iranian coast of the Persian Gulf: new collections and biogeographic considerations. Aquat. Ecosyst. Health Manage.,10(3): 341-349. doi.org/10.1080/14634980701514620

Oksnebjerg, B., Enzenross, R. and Enzenross, L. 1997. First record of Rhizocephala (Crustacea: Cirripedia) from Turkish waters with notes on lessepsian migration. Stuttgarter Beitrage zur Naturkunde Series A (Biologie), 557: $1-7$.

Ozcan, T., Katagan, T. and Kocatas, A. 2005. Brachyuran crabs from Iskenderun Bay. Crustaceana, 78(2): 237-244.

Ozcan, T. and Katagan, T. 2016. Prevalence of Heterosaccus dollfusi Boschma, 1960 (Rhizocephala: Sacculinidae) on
Charybdis longicollis Leene, 1938 (Brachyura: Portunidae) from Iskenderun Bay, Turkey, J. Black Sea/Mediterranean Environment, 22(2): 128-136.

Pereira, M. J., Branco, J. O., Christoffersen, M. L., Junior, F. F., Fracasso, H. A. A. and Pinheiro, T. C. 2009. Population biology of Callinectes danae and Callinectes sapidus (Crustacea: Brachyura: Portunidae) in the southwest Atlantic. J. Mar. Biol. Ass. U. K., 89(7): 1341-1351. DOI: $10.1017 / \mathrm{S} 0025315409000605$.

Perry, H. M. and Vanderkooy, S. J. 2015. The blue crab fishery of the Gulf of Mexico, United States: A Regional Management Plan. 2015 Revision. Gulf States Marine Fisheries Commission, 2404 Government St. Ocean Spring, MS 39564, No. 243.

Prager, M. H., Mcconaugha, J. R., Jones, C. M. and Geer, P. J. 1990. Fecundity of blue crab Callinectes sapidus, in Chesapeake Bay: biological, statistical and management considerations. Bull. Mar. Sci., 46(1): 170-179.

Rabaoui, L., Arculeo, M., Mansour, L. and Tlig-Zouari, S. 2015. Occurrence of the lessepsian species Portunus segnis (Crustacea: Decapoda) in the Gulf of Gabes (Tunisia): first recordand new information on its biology and ecology. Cah. Biol. Mar., 56: 169-175.

Sangun, L., Tureli, C., Akamca, E. and Duysak, O. 2009. Width/ length-weight and width-length relationships for $8 \mathrm{crabs}$ from the north-eastern Mediterranean coast of Turkey. J. Anim. Vet. Adv., 8(1): 75-75.

Severino-Rodrigues, E., Musiello-Fernandes, J., Moura, A. A S., Branco, G. M. P. and Caneo, V. O. C. 2013. Fecundity, reproductive seasonality and maturation size of Callinectes sapidus females (Decapoda: Portunidae) in the south-east coast of Brazil. Rev. Biol. Trop., 61(2): 595-602.

Soundarapandian, P., Varadharajan, D. and Boopathi, A. 2013. Reproductive biology of the commercially important portunid crab, Portunus sanguinolentus (Herbst). J. Mar. Sci. Res. Dev., 3: 2.

Wenner, E. L. 1989. Incidence of insemination in female blue crabs, Callinectes sapidus. J. Crust. Biol., 9(4): 587-594. doi.org/10.1163/193724089X00601.

Williams, A. B. 1974. The swimming crabs of the genus Callinectes (Decapoda: Portunidae). Fish. Bull., 72: 685-798.

Zenetos, A., Cinar, M. E., Pancucci-Papadopoulou, M. A., Harmelin, J. G., Furnari, G., Andaloro, F., Bellou, N., Streftaris, N. and Zibrowius, H. 2005. Annotated list of alien marine species in the Mediterranean with emphasis on worst invasive species. Mediterranean Mar. Sci., 6(2): 63-118. DOI: http://dx.doi.org/10.12681/mms.186. 